\title{
Structural Evolution of a Precambrian Segment: Example of the Paleoproterozoic Formations of the Mako Belt (Eastern Senegal, West Africa)
}

\author{
Mahamadane Diene $^{1 *}$, Mamadou Gueye ${ }^{1 *}$, Dinna Pathé Diallo ${ }^{2}$, Abdoulaye Dia $^{2}$ \\ ${ }^{1}$ Institut des Sciences de la Terre, Université Cheikh Anta Diop, Dakar, Senegal \\ ${ }^{2}$ Departement de Géologie, Université Cheikh Anta Diop, Dakar, Senegal \\ Email: *mahamadane@netcourrier.com, "mgueye@refer.sn
}

Received November 15, 2011; revised December 26, 2011; accepted January 28, 2012

\begin{abstract}
The western part of the Kedougou Kenieba Inlier is located in the West African Craton. It consists of paleoproterozoic NE-trending elongate belts (subprovinces) of metavolcanic and granitic rocks that alternate with metasedimentary belts. Major linear fault such as the MTZ which also approximate a north-easterly trend form the eastern boundaries. The field observations and geophysics analyses were completed by a microscopic study. Based on these data we define across this region four lithostructural domains from east to west. The western domain is structurally complex. The rocks of this domain have been subjected to a complex history of polyphase deformation and metamorphism. The structural analyse allow us to distinguished three deformation events. The deformation results in the formation of D1 thrust tectonic and D2 and D3 transcurrent tectonic. The structural evolution of the Mako Belt is characterized by deformation dominated by the intrusion of large TTG batholiths (D1) followed by basins formation and transpression accommodating oblique convergence and collision (D2 and D3). The change from thrusting (D1 deformation to transcurrent motion (D2 and D3) is recorded in the marginal basin of the central domain and in Tinkoto pull apart basin. The timing of these basins indicates a diachronous evolution. Deformation styles within the basin are compatible with a dextral transpression which terminated at ca 2090 Ma. Small extensional basins formed over the rocks of the Mako Belt are filled with continental detrital sedimentary rocks that show weak foliation and active felsic volcanism. We suggest that the sinistral transpressive tectonic associated with oblique subduction may have generated the pull-apart basin and subaqueous volcanism. In part these features are now related to terrain accretion, thrusting and strike slip movement during oblique convergence. The inversion of the large scale structural evolution from thrusting to strike slip is common to modern orogenies.
\end{abstract}

Keywords: Kedougou Kenieba Inlier; Paleoproterozoic; Transpression; Mako Belt; Oblique Convergence; Collision; Thrusting; Transcurrent

\section{Introduction}

Paleoproterozoic orogenic belts are the product of deformation, metamorphism, and plutonism. Compilation of structural data with petrologic and geochronological informations is essential to unravel their evolution. Various studies on these granite-greenstone terrains of the West African Craton (WAC), using geochemical and isotopic data have been carried out in the last decade (Bassot [1], Dia [2], Abouchami et al., [3], Boher et al., [4], Ndiaye et al., [5], Dia et al., [6], Pawlig et al., [7], Gueye et al., [8]). However the structural data and their role in the evolution of the Paleoproterozoic orogenic belts are still quite scarce in WAC, particularly in Senegal.

Knowledge of the timing of structural evolution of volcano-plutonic belts is fundamental for the understanding

${ }^{*}$ Corresponding author. of the tectonic evolution of paleoproterozoic terrains of the WAC.

The aim of this paper is to constrain the structural evolution of the volcanic and plutonic belts of the Kedougou Kenieba Inlier (KKI) particularly the Mako Belt (MB) which lies at the western margin of the KKI.

We present a new interpretation of the paleoproterozoic tectonic evolution of the Mako Belt integrating geophysical data with detailed geological studies.

\section{Geological Setting}

\subsection{The KedougouKenieba Inlier (KKI)}

The lower Proterozoic KKI (Figure 1) lies between the Taoudeni basin in the east and the senegalo-mauritanian basin in the West. It is composed of NE-trending elongate belts of metavolcanic and granitic rocks that alternate with metasedimentary belts. 


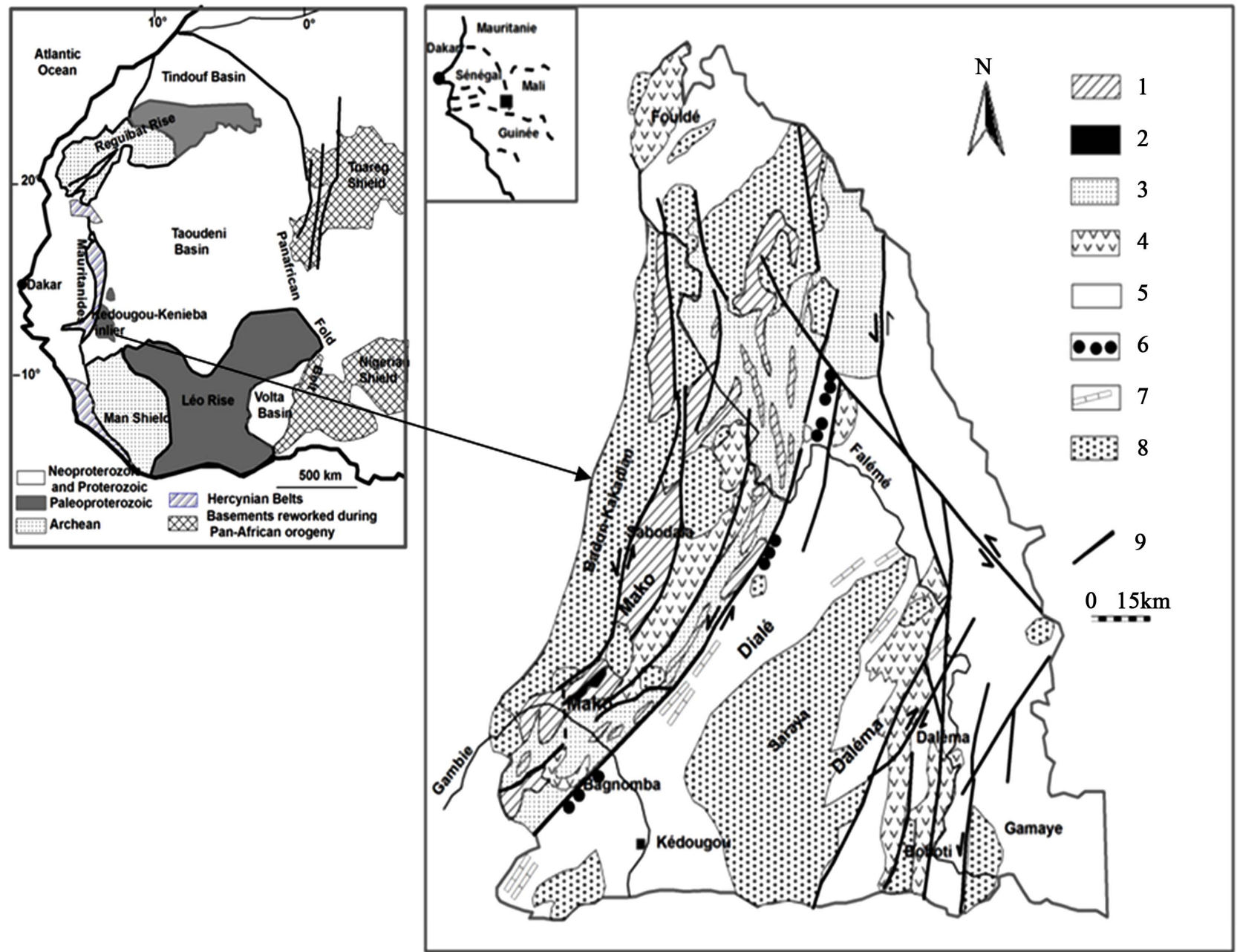

1-Basalt flows; 2-Ultrabasites; 3-Volcanodetritic rocks;

4-Andesitic flows; 5-Metasediment rocks; 6-Congomerates;

7-Carbonates; 8-Granitoids; 9-Transcurrents faults

Figure 1. The Birimianterrane of the West African Craton (WAC) with the position of the Kedougou-Kenieba Inlier (KKI). Geological map of Kedougou-Kenieba inlier. Modified after Peucat et al., 2005, Bassot, 1966; Ledru et al., 1989.

In the KKI two supergroups are represented (Bassot, [1]):

- In the west the Makosupergroup of submarine volcanics, pyroclastics and plutonic rocks

- In the east the Diale-Dalemasupergroup consisting of metasediments with intermediate volcanics and hybyssal rocks.

The KKI features a series of NE-SW trending faults with alternating high and low strain zones. Bertrand et al., [9] recognized the polycyclic character of the tectonic evolution and place the Mako supergroup at the base (lower Birimian). Milesi et al., [10] and Ledru et al., [11] agree on the polycyclic character. The classical lithology was revised by the application of geochemical data (Bassot [1], Dia [2], Abouchami et al., [3], Pawlig et al, [7]) which puts the volcanic series in a stratigraphically lower position in reference to Archean greenstone belts assemblage which are apparently very similar.

The tectonic evolution of the KKI isnot completely documented, but three major tectonic events called D1 and D2 - D3 have been defined (Milési et al., [12]; Ledru et al., [11]). The major D1 tectonic episode, which occurred around 2112 Ma to 2100 Ma (Feybesse et al., [13] and [14]), is attributed to collisional tectonics between archean and proterozoic domains. This phase was considered to be one of the principal criteria for distinguishing B1 (Lover Birimian affected by thrusting D1) from B2 (Upper Birimian affected by only two later phases transcurrent deformations D2 and D3). It was associated to deformation dominated by the intrusion of large batholiths.

The D2 and D3 phase interpreted as being between $2096 \mathrm{Ma}$ and $2073 \mathrm{Ma}$, and consequently the duration of the entire Eburnean deformation was thought to have 
been 40 Ma (Feybesse et al., [13]). The D2 phase was interpreted as transcurrent deformation along a network of ductile shear zones (Milesi et al., [12], Ledru et al., [15]) and corresponds to transpression accommodating the emplacement of the Laminia Kaourou Plutonic complex (LKPC) (Gueye, [16]). It has been long postulated that the elongated shape of most of the intrusions was due to syntectonic emplacement in relation with the activity of the shear zones (Pons [17], Gueye et al. [18]). Two geodynamic environments for the Birimiantholeiitic rocks have been proposed, either an intra-oceanic islandarc setting (Zonou [19]; Dia [2]; Sylvester and Attoh [20], Ama-Salah et al. [21], Pawlig et al. [7]) or an oceanic plateau setting (Abouchami et al. [3]; Boher et al. [4]; Pouclet et al. [22]).

\subsection{The Mako Belt (MB)}

The paleoproterozoic Mako Belt lies at the western margin of the KKI. The belt consists of greenschist to lower amphibolite facies sedimentary and volcanic successions and associated granitic and mafic intrusions. The granite plutons, including the Diombalou pluton in the north, the Layered Plutonic Complex and the Laminia Kaourou Plutonic Complex in the west, the Falombo and Bouroumbourou plutons in the centre and the Tinkoto pluton in the south are composed mainly of deformed I-type granites and undeformed leucogranites. Mafic intrusions consists of gabbros and dolerites most of which have been metamorphosed to greenschist and amphibolite facies although igneous texture (ophitic texture) are preserved. Available geochronological data show that most of the sediments and volcanic successions and granite in the MB formed in the period 2200 - $2000 \mathrm{Ma}$ and were metamorphosed and deformed at 2100 Ma based on the biotite $40 \mathrm{Ar} / 39 \mathrm{Ar}$ age of $2100 \mathrm{Ma}$ from the Badon granite, interpreted as a metamorphic age (Gueye et al, [8]). A post tectonic rhyolite that intrude the upper sequence of the $\mathrm{MB}$ yields a $\mathrm{Pb} / \mathrm{Pb}$ zircon age of $2056 \mathrm{Ma}$, which provides a minimum age for the belt.

The Mako belt has a dominant NE-SW structural trend, which deflects to an N-S direction in the north. The shape of the NE-trending greenstone belts is at least in part controlled by a network of anatomising $\mathrm{N}$ to NE-trending lineaments and shear zones. These form the boundaries of the rock units and divide it into corridor or domains. The major terrain boundary is defined as fault zone. Two main episodes of volcanism have been recognized in the Belt:

- An older succession consisting of pillow basalts;

- A younger succession consisting of massive volcanic rocks.

The older contain interlayered komatiite and tholeiitic and high-Mg basalts. Pillowed and massive basalts are interlayered with co-magmatic layered mafic sills. Greenstone succession to the east of the belt contains interlay- ered tholeiites with associated volcaniclastic rocks. The calcalkaline volcanic sequences range from basalts to rhyolites, although predominantly andesites and dacites.

Granitoids in Mako Belt fall into one of three categories: gneissic and intrusive complexes (Sandikounda and Badon), diapiric (syntectonic) plutons of variable composition Diombalou, Bouroumbourou, Falombo), late granitic plutons and rhyolite (Tinkoto, Mamakono).

Gneissic complexes and batholith which are dominantly tonalitictrondhjemite and granodiorite so-called TTG suite compose most of preserved paleoproterozoic crust. Most granite and felsic volcanics are genetically related. Detailed studies (Dia et al., [6]; Pawlig et al., [7]) of the geochemistry of the Mako belt have demonstrated that the plutons are calcalkaline and metaluminous. $\mathrm{Pb}-\mathrm{Pb}$ zircon age determination (Gueye et al., [8]) gives an age range between 2200 and 2070 and indicates the absence of older crustal material.

\section{Structural and Kinematic Analysis within the Mako Belt: New Results}

Regional deformation in the KKI is diffusely accommodated by ductile to ductile-brittle strike slip shear-zones, lateral thrusts and isoclinal folds along the Mako Belt. Deformation within the Mako Belt is found to be strongly partitioned into shear zones, which are unevenly distributed across the area. Sinistral strike-slip fault systems in the MB, with the NE-SW and N-S trending Main Transcurrent Zone (MTZ) and LeobaMoussala faults (LMFZ) respectively, are the most noteworthy features dominate. These fault zones accommodate strain localization and are responsible for complex fold interference patterns and are also associated with the emplacement of granitic plutons. They separate blocks with distinct structural-metamorphic histories. Many authors have suggested a genetic relationship between faults (or shear zones) and magmatism (Gueye et al. [18], Pons [17]).

The Mako Belt displays a prominent N-S and NE-SW structural trend resulting from regional NE to N-trending folds with axial planar schistosity that is characteristic of the belt. This schistosity (Figure 2) displays local variations in strike and dip which are attributed to either oblique fault crosscutting the regional trend or deformation aureole around resistant plutonic suites, although in general steeply-dipping fabrics are prevalent in the Mako Belt. Shallow dipping fabrics are recorded and are often related to late thrusting. The belt-wide fold pattern that corresponds to a series of $\mathrm{N}$-trending synclines, is occupied by the sedimentary basins and anticlines which are generally cored by plutons. The first generations of structures we recognize are a series of gently to steeply-plunging mesoscopic folds, which are pervasive through the pillows and are sometimes difficult to identify because they have been transposed, dismembered, or refolded (Figure 3). 


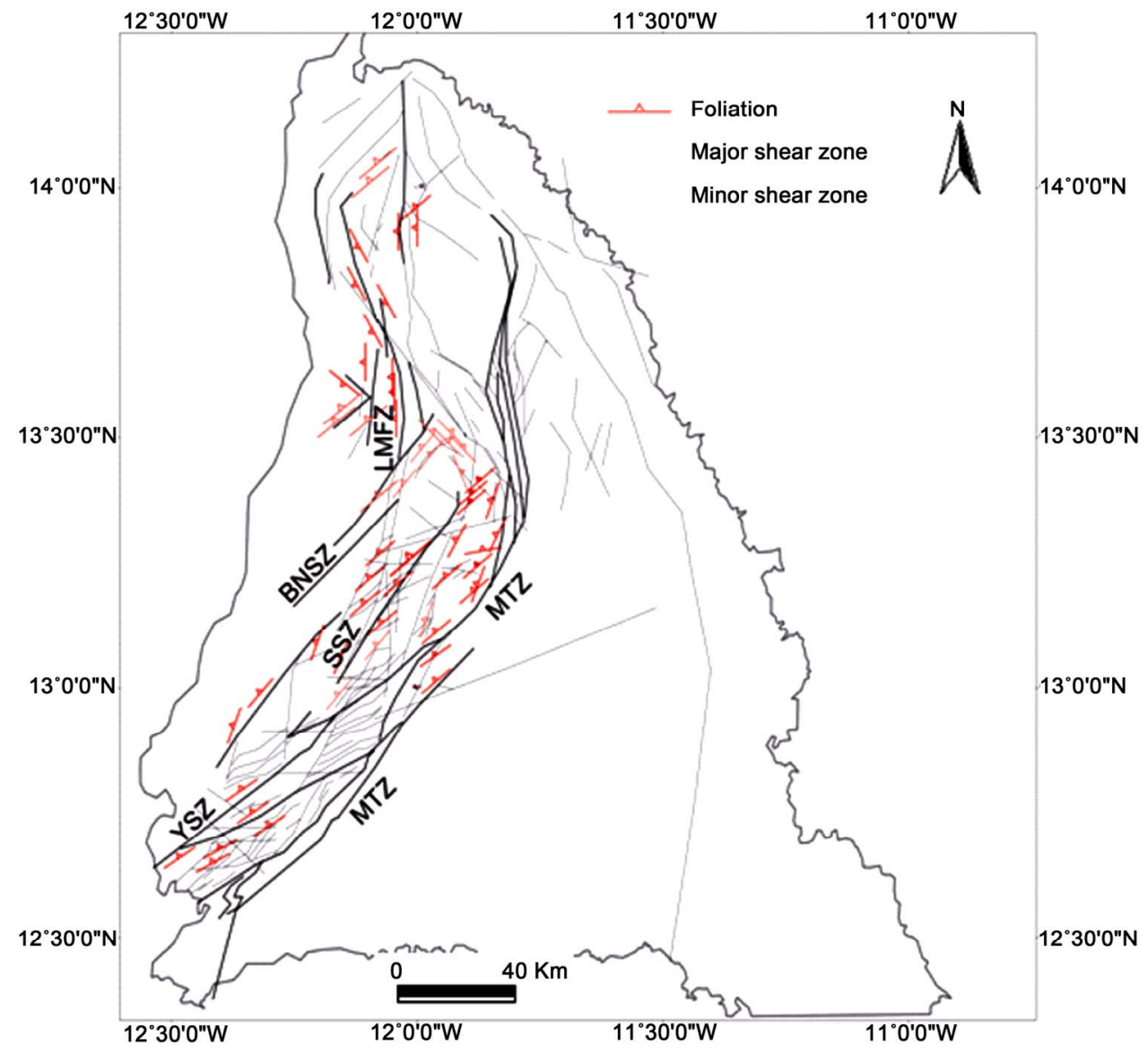

Figure 2. Foliation trajectories within the Mako Belt. (MTZ: main transcurrent zone; SSZ: Sabodala shear zone; BNZS: Badon-Niéniéko shear zone; YTZ: Yaaka transcurrent zone; LMSZ: Léoba-Moussala shear zone).
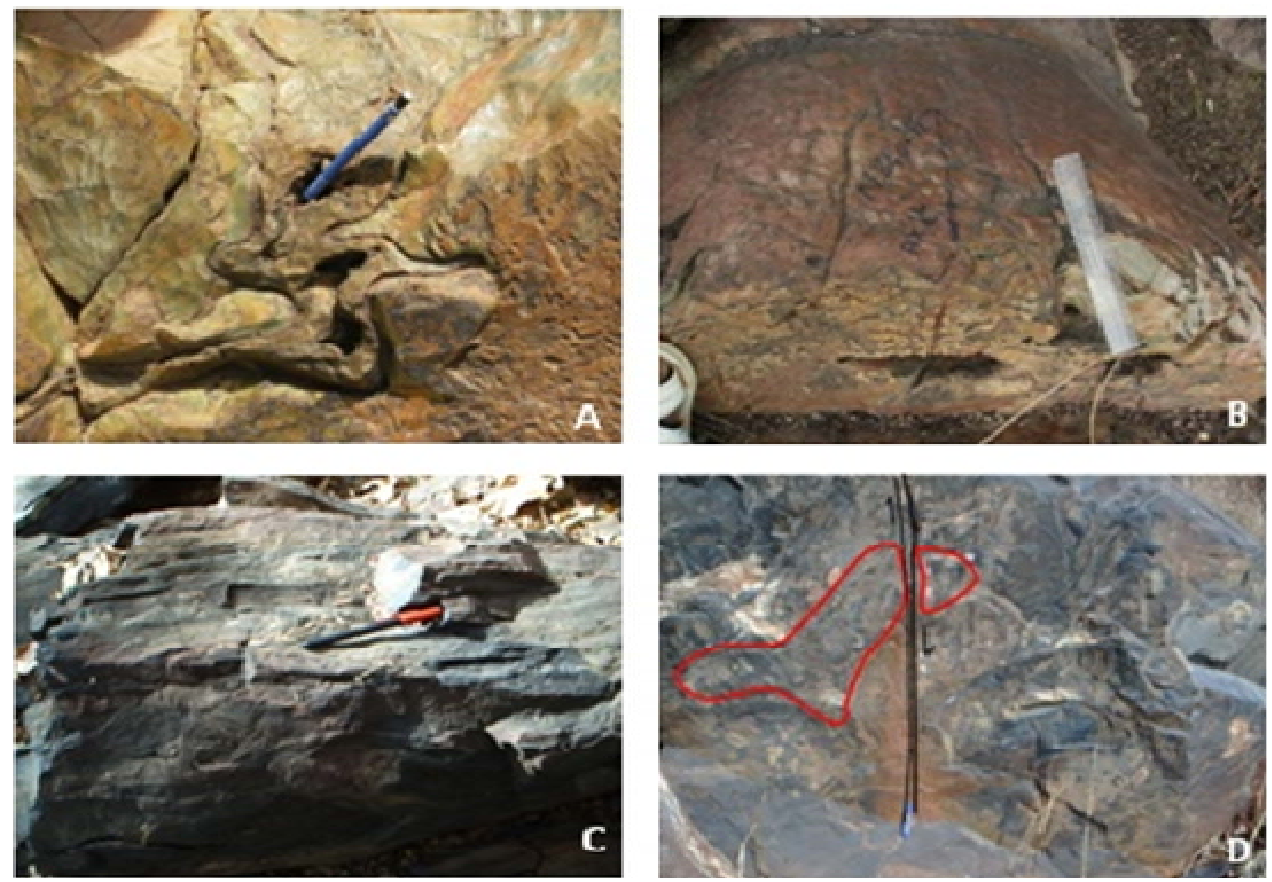

Figure 3. Photographs showing some example of superposed folds in the pillowed lavas. A: Superposed folds; B: Sheath fold; $\mathrm{C}$ and D: Pillow transposed in the foliation plane. 


\subsection{The Main Tectonic Events}

Three principal episodes of ductile to semi-ductile eburnean deformation have been recognized in the studiedarea. Macro-, meso- and microstructures within the belt can be described in terms of D1, D2 and D3 deformational episodes.

\subsubsection{The D1 Phase}

The oldest deformation structures (D1) are preserved in xenoliths within the undeformed parts of the Sandikounda Layered Complex, the second oldest recognised intrusive component of the Mako Belt. In this area, thrusting SE-verging deformation took place and is characterized by a series of imbricate banded gneisses, volcaniclastics and volcanic rocks dipping $40^{\circ} \mathrm{NW}$, with asymmetric folds. Thrusting is post dated by the emplacement of the Sandikounda Layered Plutonic complex (SLPC), placing a tight constraint of 2160 - $2140 \mathrm{Ma}$ (Dia et al., [6]).

The preservation of flat lying thrusts in greenstone belts is rare because thrusts are commonly refolded into tight upright orientations due to subsequent shortening.
Features suggesting that the Sandikounda Fault is a thrust, are well developed in the Tonkoutou area. Dip parallel stretching lineations are present. Schematic geological cross-section NW-SE in this area (Figure 4), shows a stacking of units to high grade metamorphism formed by amphibolo-gneiss, on weakly metamorphic units formed by the metabasalts, the volcaniclastic and layered plutonic complex. The relationship between the foliation and lineation, as well as recumbent folds, shows a thrust character with a SE-verging which would have affected the lithological stack in this sector of Sandikounda.

This style characterizes a thrust deformation and is observable in this sector of Sandikounda.

However, some features of this thrusting, were affected by subsequent phases of deformation but also by the phenomena affecting migmatization amphibolites which are due probably by the large heat flow accompanying the introduction of the layered plutonic complex.

The reverse component of movement, deduced from the juxtaposition of higher grade metamorphic rocks over lower-grade metamorphic rocks changes the structural interpretation of the area.

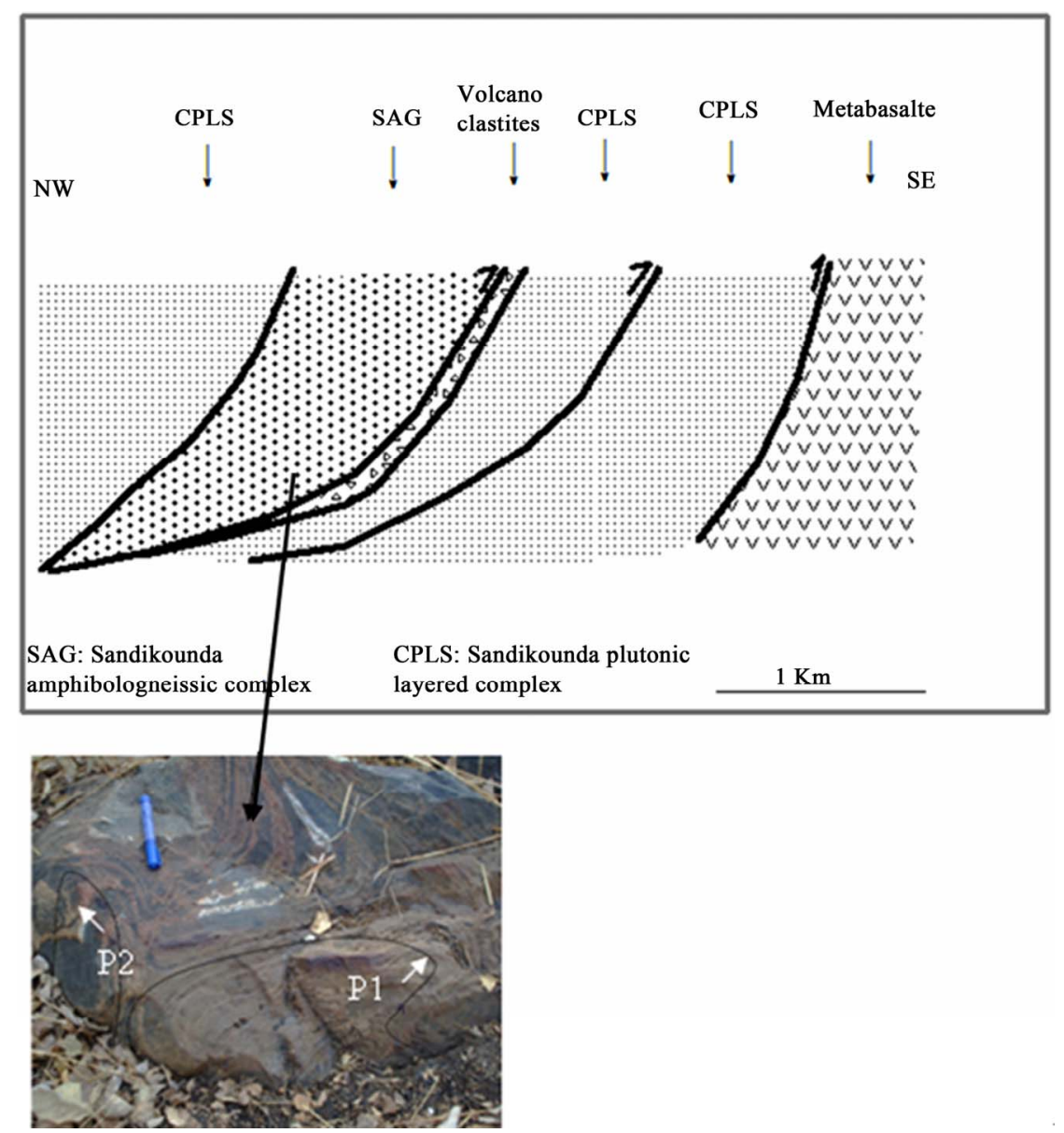

Figure 4. Schematic cross-section showing the tectonic contact between the Sandikounda amphibologneiss complex and the metabasalts in Sandikounda area. Photograph in vertical section shows the superposed folds. 


\subsubsection{The D2 Phase}

The NW-SE compression event, which we will name D2 in accordance with the classical terminology (Milési et al., [12]; Ledru et al., [11]; Feybesse et al., [13]), is undoubtedly responsible for the map scale structures. $\mathrm{N}$ to NE-trending structures developed in the shear zone during D2 as the result of sinistral shear, are partially affected by late deformation. The D2 phase is characterized by a NE-SW to N-S subvertical foliation associated with assymmetric folds and astretching lineation parallel to the axial planes of the fold. The stretching lineation plunges gently (subhorizontal) or more steeply in the strikeslip fault.

The D2 structures have been interpreted as the result of eburnean NW-SE horizontal shortening in a transpressive regime under amphibolite facies condition (Gueye [16]).

The predominantly transpressional regime represents a major change in tectonic style in the Mako Belt. Steep sinistral strike slip shear zones were produced during this
D2 transpressional stage.

\subsubsection{Transcurrent Faults}

The north east trending faults: example of the Main Transcurrent Zone (MTZ)

The $125 \mathrm{~km}$ wide MTZ (Figure 5) of SE Senegal and Mali formed as a result of transcurrent motion between two major crustal blocks namely Mako and Diale-Dalema. Previously this shear zone was considered to be a continuous lineament but our recent structural studies show that it is divided into northern and southern branches. Ductile deformation is reflected in tight folding with steeply dipping foliation.

Numerous structural signatures (shear sense indicators) were identified along the strike of the MTZ, ranging from dextral strike slip in the southern segment (Figures 6(b)-(c)) of the fault zone to sinistral strike slip in the Malian part (Figure 6(a)). The fault is composed of bands of higher shear strain alternating with lower strain domains.

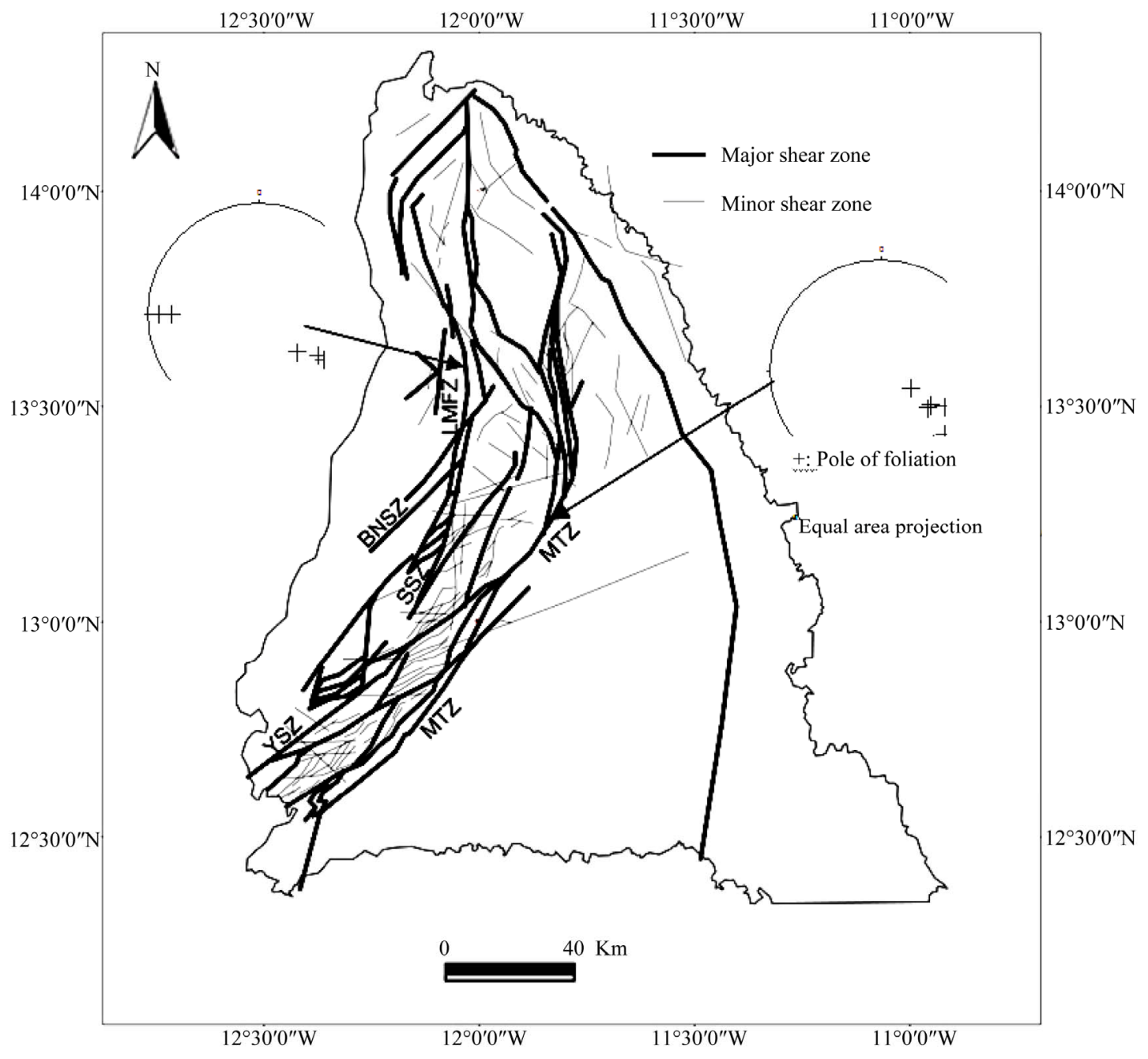

Figure 5. Structural map of the Mako Belt showing the position of the main faults zones MTZ and LMFZ. Stereoplots showing the main $\mathrm{NE}$ and $\mathrm{N}$-trending mylonitic foliation. 

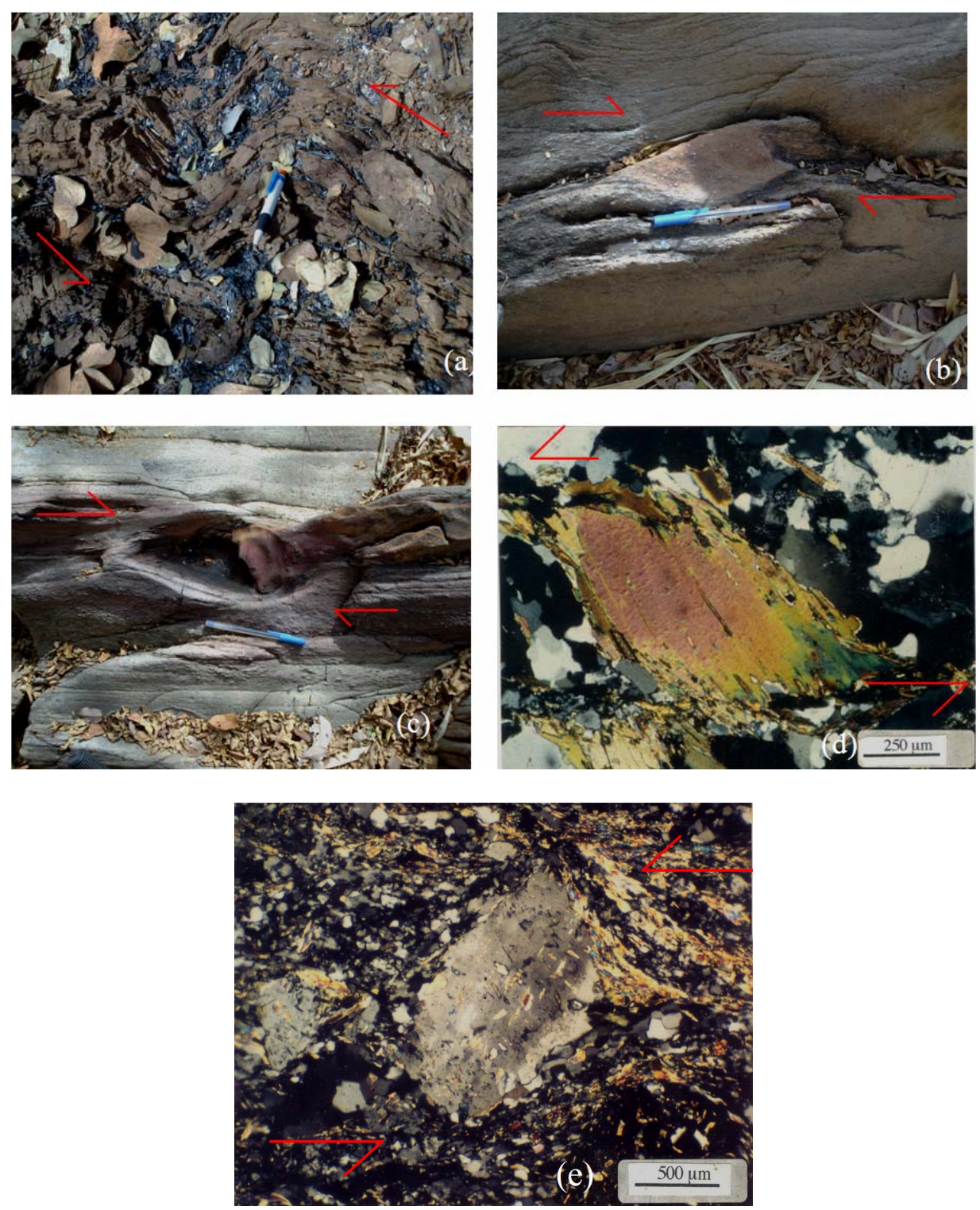

Figure 6. Photographs in vertical section and photomicrographs showing some example of shear sense indicators such as observed along the MTZ and the LMFZ. (a) S-shaped fold which affects the mylonitic foliation of the MTZ; (b) and (c): Sedimentary units of the MTZ displaying delta-shape structure that indicate sinistral sense of movement; (d) and (e) Mica fish and delta-shaped clast indicating sinistral sense of movement along the LMFZ.

\subsubsection{North-South-Trending Faults: Example of the Leoba Moussala Fault Zone (LMFZ)}

The LMFZ (Figure 5) represent a major N-trending shear zone located in the central zone of the Belt. It is characterized by the development of sinistraltranscurrent shear sense indicators (Figures 6(d)-(e)) (e.g. Gueye [16]). The fault features a wide deformation zone with a pervasive subvertical mylonitic fabric and a subhorizontal stretching lineation. Shear sense indicators indicate sinistral sense of movement.

The stretching lineation, which developed in coarsely clastic rocks, has a pronounced oblate geometry, indicating significant flattening strains. The geometrical rela- tionship between the shear sense indicators and stretching lineation is generally interpreted to be the product of transpressional shear, a regime of shear zone boundary parallel transcurrent movement accompanied by a large amount of shear-zone-normal stretching. The timing of the shear movement within the LMFZ is constrained by the crystallization of the Kaourou monzogranite at 2130 Ma (Gueye [16]).

\subsubsection{The Late Phase D3}

The main structures of this phase are found in the Mako Belt in the Sonkounkou and Kossanto area. They comprise dextral transcurrent to slightly oblique well-developed 
greenschist facies shears with consistently west-plunging stretching lineations. Locally D3 produces minor asymmetric $\mathrm{Z}$ folds. D3 asymmetric fold axes tend to be collinear with the D2 stretching lineation. Brittle-ductile to brittle structures, including the dominantly $060^{\circ}-070^{\circ}$-trending crenulation cleavage, kink sets and dextral $-070^{\circ}-080^{\circ}$ trending faults and asymmetric folds overprint the above dextral greenschist facies shear but fit the same NW-SE compressional framework. We interpret the structures to have developed during one continuous phase of NW-SE compression and oblique convergence. Absolute age constraints for this phase are not available, but it postdates the intrusion of the Mamakono, Tinkoto and Saraya plutons (age range between 2080 and $2070 \mathrm{Ma}$ ).

\section{Tectonic Subdivisions of the Mako Belt}

Recent works provide a significant amount of new structural metamorphic, geochemical and geochronological data constraining the geodynamic evolution of the Mako belt (Bassot [1], Dia [2], Abouchami et al., [3], Pawlig et al., [7]). We propose a new definition of the lithotectonic units and distinguish from west to east: many basaltic segments are distinguished in the plutonic-volcanic complex and correspond to the Sandikounda, the Sabodala and the Mako segments; marginal basins and pull-apart basins (Figure 7).

\subsection{The Plutonic-Volcanic Complex}

It forms a narrow band of magmatic and metamorphic rocks. It is best exposed within the Badon-Sandikounda area. The meta-lavas range in composition from basalt to rhyolite but are dominated by dacite and andesite in the southern domains. The volcanic, volcanoclastic sequence is intruded by various dykes, sills of trondhjemites and metagabbros. Metamorphic conditions grade from greenschistfacies in the southern part of the domain to amphibolite and granulite facies and local anatexis in the Sandikounda area (Gueye et al., [18]).

\section{Sandikounda Segment}

The Sandikounda segment is considered to be an oceanic arc island composed of tholeiitic basalts overlain by a mafic-to-felsic volcanic calc alkaline sequence. Maficultramafic massive, pillowed and volcanoclastic rocks are highly strained.

The western margin is a fault contact against uplifted basaltic basement, whereas the eastern margin is a fault. The eastern margin is more structurally complex and lineation and folds are indicative of two fold sets at high angles.

Clast elongation in the volcanoclastic rocks of the Sandikounda area in the footwall also have NW plunges, thereby suggesting that folds in the hanging wall have been

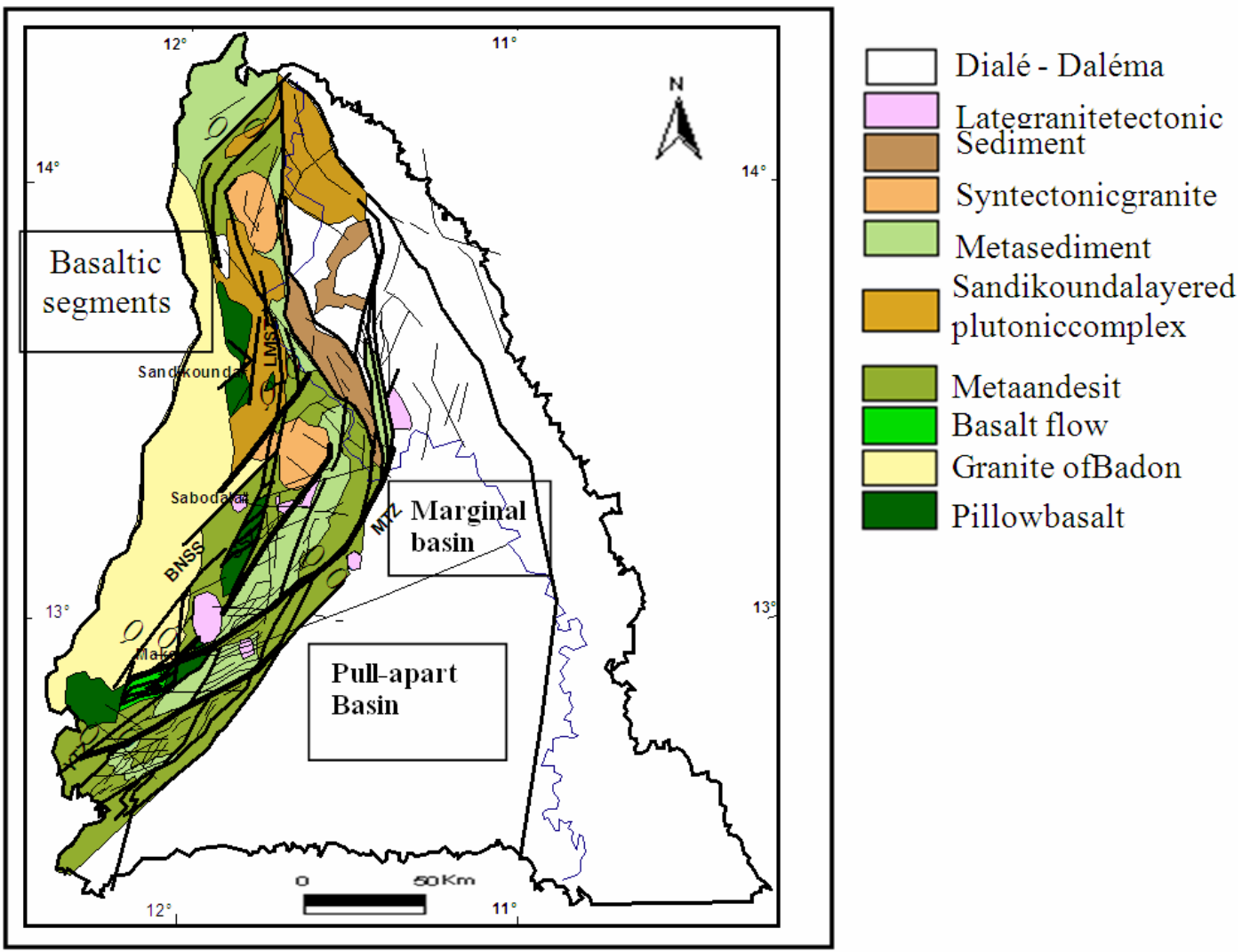

Figure 7. Major divisions in the Mako Belt. 
rotated. Total X/Z strain states calculated from rounded volcanic elements range from 4:2 in the hanging wall volcanoclastics. These features are indicative of thrusting of the gneiss over the volcanic succession.

\subsection{The Marginal Basins}

These basins occupy a marginal position with respect to the plutonic-volcanic complexes and are filled by turbidites derived from volcanic-volcanoclastic rocks. They are composed of volcanic, volcanoclastic sequences intruded by abundant plutonic rocks. The metavolcanics of these basins are dominated by intermediate to felsic rocks. They are characterized by breccia and coarse pyroclastics sequence, which grade into finer grained tuff and epiclatites interlayered with cherts and carbonates. Closure of the basins accommodates the emplacement of the calcalkaline plutons (Bouroumbourou and Diombalou). Metamorphism is characterized by widespread greenschist to amphibolite facies conditions with local anatexis near the plutons. Crystallization of andalusite porphyroblasts is limited to graphitic sequence in the vicinity of the Bouroumbourou pluton. The low pressure and intermediate temperature metamorphism suggested by this assemblage are consistent with widespread contact metamorphism related to intrusion of plutonic rocks.

However, we have some sedimentary units dominated by the flysch of the Sonkounkou formation. The schists of the Soreto formation consist of flysch-like sedimenttary sequences characterized by folded rhythmic alternations of graded greywackes-sandstone and tuff layers.

The basins were mainly filled with minor greywacke and flysch-type sediments containing minor intercalations of basic and acid volcanic rocks. The basins are thus interpreted as flysch (foreland basins).

\subsection{The Pull-Apart Basins}

We found these basins to the north (Diombalou Basin) and the south (Tinkoto basin)

\subsubsection{Diombalou Basin}

The Diombalou Basin is a lozenge shaped basin delineated by faults. From the base to the top the sedimentary pile is made of arkosic sandstones including larges lenses of conglomerates, sandstone and shale, lava and pyroclastic flow are interbeded in the lower part of the pile. Most of the lavas are andesities. A few lavas are andesitic dacites. All the formations were affected by upright folding and shearing along NE-SW transcurent shear zone corridors. Some small pluton of biotite granite intruded the deeper part of the basin, while a huge batholith of leucogranite was emplaced on the western side.

Thermal metamorphism of the peliticshales produced hornfels at the granite contact and staurolite and kyani- teschists in the neighbouring zone. Volcanic andesitic activity is coeval with basin formation (Fouldé).

\subsubsection{Tinkoto Basin}

Within the Tinkoto area (Figure 8), sedimentary rocks formed a lozenge shaped entity delineated by faults. Pullapart basin developed within calk-alkaline magmatism and metamorphism localized within the fault zone. This was followed by a phase of compression. The Tinkoto basin was interpreted as a sinistral fault wedge basin, a type of pull-apart structure formed along the western fault splay of the MTZ. The Tinkoto basin was initiated after the accretion of the volcanic rocks of the marginal basins. It was initiated before $2070 \mathrm{Ma}$ as indicated by the age of the Tinkoto pluton.

The southern domain to the Mako belt, consists of bimodal mafic and felsic volcanic rocks erupted during major cycles of volcanism. Intrusion of the younger granodiorite caused local amphibolite facies contact metamorphism that overprints nearby the volcanic complex. Additional dikes and sills, ranging from gabbro to quartz diorite, occur throughout the domain. The main structural elements in the southern domain are dominantly N-S to NNE-SSW and NW-SE oriented synvolcanic and later reactivated faults.

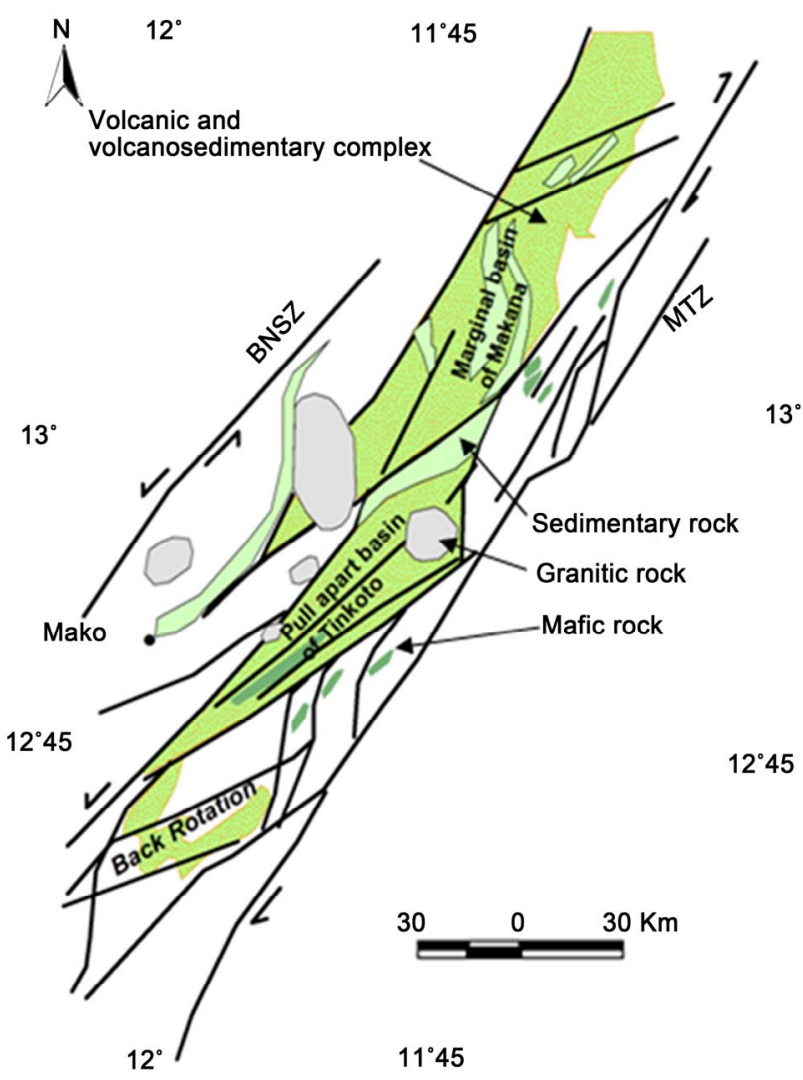

Figure 8. Structural characteristics of the pull-apart basins: diachronic evolution of the Tinkoto basin and the Makana marginal basin. 


\section{Tectonic Significance}

The tectonic evolution of the Paleoproterozoic Mako Belt in the West African Craton is explained by a various structural elements in the four domains. Concerning the previous tectonic structures, the D1 event should be compatible with thickening processes. In this tectonic context, high-temperature low pressure metamorphism conditions and huge amounts of granite should be present. As in other Paleoproterozoic regions, the geodynamic significance of this horizontal tectonic structure can be attributed to lithospheric convergence in a plate tectonic setting (e.g. Feybesse et al., 2006).

The D2 bulk strain pattern is clearly related to a transpressional regime during bulk horizontal shortening of heated crust. This transpression, contemporaneous with amphibolite facies conditions, resulted in a strain partitioning between the anastomosing shear zone network in the volcanic plutonic complex and the folded marginal domain.

The dome-and-marginal basin domains are folded under a pure shear-dominated strain regime, whereas the shear zones show a component of the simple shear regime.

Inside the shear zones the strain also varies, from simple to pure shear, depending on their positions in space. The vertical shear zone separate this two domains, recording different pressure conditions. These regional pressure differences, controlled by kilometric tectonic structures, are compatible with exhumation during compression under a transpressive regime (D2 strain pattern). The amount of uplift that juxtaposes contrasted metamorphic domains was controlled by the D2 strain gradient.

This hypothesis is confirmed by the strain gradient increases in domains from west to east.

Towards the end of the Paleoproterozoic it is proposed that there was a change in the pattern of crustal growth such that new crust was added as long narrow belts of accretionary complexes along the margins of the older plutonic volcanic complex.

\section{Discussion and Conclusions}

\section{Makobasin-Volcanism and Tectonics: Correlation between Oblique Convergence, Basin Formation and Magmatism}

An apparent correlation between plutonism, oblique convergence and associated strike slip faulting observed in the study area suggest that D2 faulting was responsible for the basin formation. Basin subsidence, submarine volcanism and plutonic activity occurred in close spatial and temporal relationship within the Mako volcano-plutonic arc during the paleoproterozoic oblique convergence, indicating that sinistral transpression was the trigger of pullapart basin formation and magmatism. Aligned syntectonic granitic intrusions and small pull-apart basins indicate local transtensional structures concurring with the bulk transpressional regime.

The structural evolution of the Mako Belt (Figure 9) is characterized by:
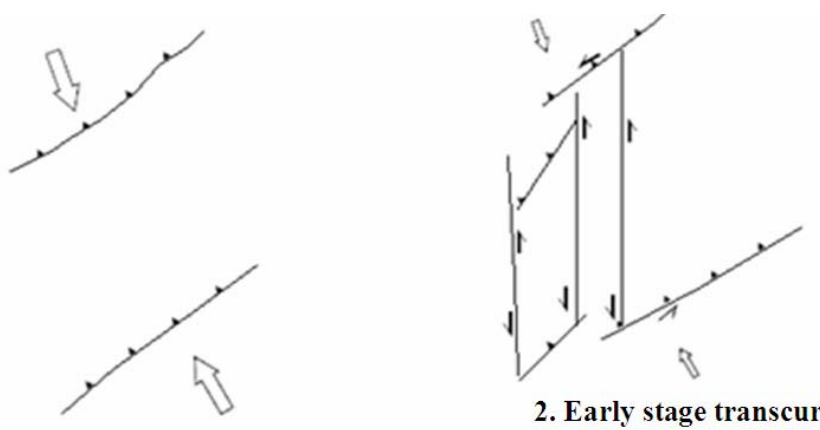

2. Early stage transcurrent

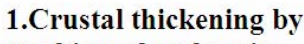
stacking of rock units

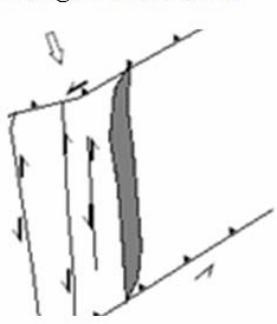

3. Establishment of basin type II through transform faults NS

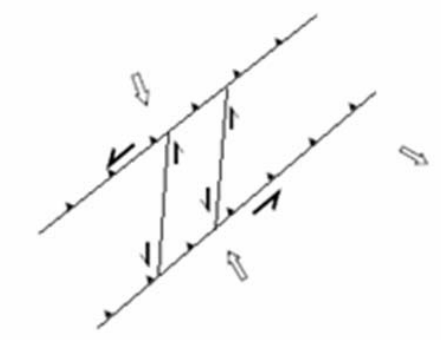

4. N-S sinistraltranspression

Figure 9. General model for the evolution of the Mako Belt in plan view explaining the formation of the marginal Makana basin and the late oblique convergence. 
- D1 thrust tectonism causing crustal thickening. This deformation was accompagnied by the intrusion of large TTG batholiths.

- Followed by transpression accommodating oblique convergence and collision (D2).

- Progressive burial of the sedimentary basins occurs in the northern part of the belt and is followed by extrusion of the Bouroumbourou area.

- An early phase of south-eastward thrusting followed by a compressionnal NS phase, the whole being followed by a late phase of extension. The broad zone in the Sandikounda area records a progressive deformation sequence that includes early compressional structures modified by sinistral transpression. The rheologically rigid segments deflected deformation and was domed, rotated and boudinaged because of its resistance to compression. The partitioning of the structures in the domains is further dependent upon rheology difference. The volcanic activity was initiated immediately after the rapid bloc uplift of the pillow lavas and become widespread all over the belt providing sub aerial lava flows and pyroclastics products.

Deformation styles within the basin are compatible with a dextral transpression which terminated at ca 2090. Small extensional basin formed over the rocks of the Mako Belt. The basins are filled with continental detrital sedimentary rocks that show weak foliation and active felsic volcanism.

The transpressive shear zone may result from oblique convergence of the volcanic Mako domain and sedimenttary Dalema domain following an early phase of thrusting.

Some transcurrent shear zones of the KKI display dextral displacements. These are the Mako Kanoumering Shear Zone. This opposite shear sense can be explained by oblique convergence. These occur along releasing bends, and are related to E-W, NE-SW and NW-SE-trending fault. The thrust signature was either synchronous or late with respect to the emplacement of these phases.

This interpretation is in agreement with mechanisms related to oblique convergence, the later being typically resolved into a strongly orthogonal compressionnal component at the strike slip component.

The inversion of the large scale structural evolution from thrusting to strike slip is common to modern orogenies. The east-west shear zones either initiated as late thrust faults that were reactivated as dextral strike-slip faults, or are dextral transpression zones which accommodated the oblique convergence of the volcanic domain. Strain partitioning into transcurrent deformation along the LeobaMoussala shear zone and NE-SW oriented shortening in the marginal basins, is consistent with a sinistral transpressional regime during the second phase of deformation. Transcurrent deformation continued during cooling of the entire belt, giving rise to the localized low-temperature mylonite.

The proposed structural evolution of the MB is consistent with the models of Feybesse et al., [14] and Lompo [23], for the eburnean orogeny. These authors recognize three phases of deformation D1, D2 and D3. Our interpretation led us to define an early D1 tectonism, is in agreement with Milési et al. [24]; Allibone et al. [25], who also recognize the existence of an early event D1 in Eburnean orogeny. In this, we differ from the interpretation of some authors (Eisenlohr and Hirdes, [26]; Blenkinsop et al., [27]) who propose that all Eburnean structures are related to single event may correspond to our D2 and D3 phases.

The crustal shortening with Southeast directed is related to a NW-SE compression. This is in agreement with Blenkinsop et al., [27]; Vidal and Alric [28]; Allibone et $a l$. [29], who note that all Eburnean structures are related to a NW-SE compression.

Regionally significant sinistrallytranspressive deformation at ca 2140 Ma was accompanied by intracrustal melting, migmatization and granitoid emplacement. We suggest that the sinistral transpressive tectonic associated with oblique subduction may have generated basins and subaqueous volcanism. Our interpretation follows that of Vanderhaeghe et al., [30], who note that the Transamazonian orogeny was marked by oblique convergence characterized by the development of pull-apart basins and marginal basins.

\section{REFERENCES}

[1] J. P. Bassot, "Le Complexe Volcanoplutonique Calco Alcalin de la Rivière Daléma (Est du Sénégal): Discussion de la Signification Géodynamique Dans le Cadre de l’Orogenèse Eburnéenne (Protérozoïque Inférieur),” Journal of African Earth Sciences, Vol. 6, No. 4, 1987, p. 25.

[2] A. Dia, "Caractères et Significations Des Complexes Magmatiques et Métamorphiques du Secteur de Sandikounda-Laminia (Nord de la Boutonnière de Kédougou, est du Sénégal ). Un Modèle Géodynamique du Birimien d'Afrique de l'Ouest," Thèse d'Etat, Dakar, 1988.

[3] W. Abouchami, M. Boher, A. Michard and F. Albarede, "A Major 2.1 Ga Event of Mafic Magmatism in West Africa: An Early Stage of Crustal Accretion,” Journal of Geophysical Research, Vol. 95, No. B11, 1990, pp. 17605-17629. doi:10.1029/JB095iB11p17605

[4] M. Boher, A. Michard, F. Albarede, M. Rossi and J. P. Milési, "Crustal Growth in West Africa at 2.1 Ga," Journal Of Geophysical Research, Vol. 97, No. B1, 1992, pp. 345-369. doi:10.1029/91JB01640

[5] P. M. Ndiaye, A. Dia, A. Vialette, D. P. Diallo, P. M. Ngom, M. Sylla and S. Wade, "Les Granitoïdes du Protérozoïde Inférieur du Supergroupe de Dialé-Daléma. Données Pétrographiques, Géochimiques et Géochronologiques Nouvelles,” CIFEG, Publication Occasionnelle, Paris, 1993.

[6] A. Dia, W. R. Van Schmus and A. Kröner, "Isotopic 
Constraints on the Age and Formation of a Paleoproterozoic Volcanic Arc Complex in the Kedougou Inlier, Eastern Senegal, West Africa," Journal of African Earth Sciences, Vol. 24, No. 3, 1997, pp. 197-213. doi:10.1016/S0899-5362(97)00038-9

[7] S. Pawlig, M. Gueye, R. Klischies, S. Schwars, K. Wemmer and S. Siegesmud, "Geochemical and Sr-Nd Isotopic Data on the Birimian of the Kedougou-Kenieba Inlier (Eastern Senegal): Implications on the Palaeoproterozoic Evolution of the West African Craton," South African Journal of Geology, Vol. 109, No. 3, 2006, pp. 411-427.

[8] M. Gueye, S. Siegesmund, K. Wemmer, S. Pawlig, M. Drobe, N. Nolte and P. Layer, "New Evidences for an Early Birimianevolutionin the West African Craton: An Example from the Kédougou-Kénieba Inlier, Southeast Senegal," South African Journal of Geology, Vol. 110, No. 4, 2007, pp. 511-534. doi:10.2113/gssajg.110.4.511

[9] J. M. Bertrand, A. Dia, E. Dioh and J. P. Bassot, Réflexions sur la Structure Interne du Craton Ouest -Africain au Sénégal Oriental et des Confins GuinéoMaliens," Comptes Rendus de l'Académie des Sciences, Vol. 309, 1989, pp. 751-756.

[10] J. P. Milési, M. Diallo, J. L. Feybesse, E. Keïta, P. Ledru, C. Vichon and A. Dommanget, "Caractérisation Lithostructurale de Deux Ensembles Successifs dans les séries Birimiennes de la Boutonniére de Kédougou (MaliSénégal) et du Niandan (Guinée): Implications Gîtologiques,” CIFEG, Publication Occasionnelle, 1986, pp. 113-121.

[11] P. Ledru, J. Pons, J. P. Milési, A. Dommanget, V. Johan, M. Diallo and C. Vinchon, "Tectonique Transcurrente et Evolution Polycyclique dans le Birimien, Protérozoïque Inférieur, du Sénégal-Mali (Afrique de l’Ouest)," Comptes Rendus de l'Académie des Sciences, Vol. 308, 1989, pp. 117-122.

[12] J. P. Milési, J. L. Feybesse, P. Ledru, A. Dommanget, M. F. Ouedraogo, E. Marcoux, A. Prost, C. Vinchon, J. P. Sylvain, V. Johan, M. Tegyey, J. Y. Calvez and P. Lagny, "Les Minéralisations Aurifères de l'Afrique de l'Ouest: Leurs Relations avec l'Evolution Lithostructurale au Protérozoïque Inférieur,” Chronique de la Recherche Minière, Vol. 497, 1989, pp. 3-98.

[13] J. L. Feybesse, J. P. Milési, Y. Johan, et al., "La Limite Archéen-Protérozoïque d'Afrique de l'Ouest: Un Zone de Chevauchement Antérieure à l'Accident de Sassandra; l'Exemple des Régions d'Odienné et de Touba (Côte d'Ivoire)," Comptes Rendus de l'Académie des Sciences, Vol. 309, 1989, pp. 1847-1853.

[14] J. L. Feybesse, M. Billa, C. Guerrot, E. Duguey, J. L. Lescuyer, J. P. Milési and V. Bouchot, "The Paleoproterozoic Ghanaian Province: Geodynamic Model and Ore Controls, Including Regional Stress Modelling," Precambrian Research, Vol. 149, No. 3-4, 2006, pp. 149-196. doi:10.1016/j.precamres.2006.06.003

[15] P. Ledru, J. Pons, J. P. Milésie, J. L. Feybesse and V. Johan, "Transcurrent Tectonics and Polycyclic Evolution in the Lower Proterozoïc of Senegal-Mali,” Precambrian
Research, Vol. 30, 1991, pp. 337-354.

[16] M. Guèye, “Transcurrent Fault Propagation and Granitoïdeplutonism during Lower Proterozoictranspression (SE Sénégal),” Zeitschrift der Deutschen Geologischen Gesellschaft, Vol. 152, No. 24, 2001, pp. 175-198.

[17] J. Pons, P. Barbey, D. Dupuis and J. M. Leger, "Mechanisms of Plutonemplacement and Structural Evolution of a 2.1 Ga Juvenile Continentalcrust: The Birimian of Southwestern Niger," Precambrian Research, Vol. 70, No. 3-4, 1995, pp. 281-301. doi:10.1016/0301-9268(94)00048-V

[18] M. Gueye, P. M. Ngom, M. Diène, Y. Thiam, S. Siegesmund, K. Wemmer and S. Pawlig, "Intrusive Rocks and Tectono-Metamorphic Evolution of the Mako Paleoproterozoic Belt (Eastern Senegal, West Africa),” Journal of African Earth Sciences, Vol. 50, No. 2-4, 2008, pp. 88110. doi:10.1016/j.jafrearsci.2007.09.013

[19] S. Zounou, "Les Fonnations Leptyno-Amphibolitiques et le Complexe Volcanique et Volcano-Sédimentaire du Protérozoïque Inférieur de Bouroum-Nord (Burkina-FasoAfrique de l’Ouest). Etude Pétrographique, Géochimique, Approche Pétrogénétique et Evolution Géodynamique," Thèse d'Etat, University Nancy l, 1987.

[20] P. J. Sylvester and K. Attoh, "Lithostratigraphy and Composition of 2.1 Ga Greenstone Belts of the West AfricanCraton and Their Bearing on Crustal Evolution and theArchean-Proterozoic Boundary,” Journal of Geology, Vol. 100, No. 4, 1992, pp. 377-393. doi:10.1086/629593

[21] I. Ama-Salah, J. P. Liégeois and A. Pouclet, "Evolution d'un Arc Insulaire Océanique Birimien Précoce au Liptako Nigérien (Sirba): Géologie, Géochronologie et Géochimie,” Journal of African Earth Sciences, Vol. 22, 1996, pp. 235-254.

[22] A. Pouclet, M. Vidal, C. Delor, Y. Siméon and G. Alric, "Le Volcanisme Birimien du Nord-Est de la Côte d'Ivoire, Mise en Evidence de Deux Phases Volca-Tectoniques Distinctes dans l'Evolution Géodynamique du Paléoprotérozoïque," Bulletin de la Société Géologique de France, Vol. 167, 1996, pp. 529-541.

[23] M. Lompo, "Geodynamic Evolution of the 2.25-2.0 GaPalaeoproterozoic Magmatic Rocks in the Man-Leo Shield of the West African Craton. A Model of Subsidence of an Oceanic Plateau," Geological Society, London, Special Publications, Vol. 323, 2009, pp. 231-254.

[24] J. P. Milési, P. Ledru, P. Ankrah, V. Johan, E. Marcoux and Ch. Vinchon, "The Metallogenic Relationship between Birimian and Tarkwaian Gold Deposits in Ghana," Mineralium Deposita, Vol. 26, 1991, pp. 228-238.

[25] A. Allibone, J. Teasdale, G. Cameron, M. Etheridge, P. Uttley, A. Soboh, J. Appiah-Kubi, A. Adanu, R. Arthur, J. Mamphey, B. Odoom, J. Zuta, A. Tsikata, F. Pataye and S. Famiyeh, "Timing and Structural Controls on Gold Mineralization at the Bogosa Gold Mine, Ghana, West Africa,” Economic Geology, Vol. 97, 2002, pp. 949-969.

[26] B. N. Eisenlohr and W. Hirdes, “The Structural Development of the Early Proterozoic Birimian and Tarkwaian Rocks of Southwest Ghana, West Africa," Journal of African Earth Sciences, Vol. 14, No. 3, 1992, pp. 313-325. doi:10.1016/0899-5362(92)90035-B 
[27] T. Blenkinsop, A. Schmidt Mumm, R. Kumi and S. Sangmor, "Structural Geology of the Ashanti Gold Mine," Geologisches Jahrbuch, Vol. 100, 1994, pp. 131-153.

[28] M. Vidal and G. Alric, “The Paleoproterozoic (Birimian) of Haute-Comoé in the West African Craton, Ivory Coast: A Transtensional Back-Arc Basin,” Precambrian Research, Vol. 65, No. 1-4, 1994, pp. 207-229. doi:10.1016/0301-9268(94)90106-6

[29] A. Allibone, T. C. McCuaig, D. Harris, M. Etheridge, S. Munroe, D. Byrne, J. Amanor and W. Gyapong, "Str- uctural Controls on Gold Mineralization at the Ashanti Gold Mine, Obuassi, Ghana,” Society of Economic Geologists Special Publication, 2002, pp. 65-93.

[30] O. Vanderhaeghe, P. Ledru, D. Thiéblemont, E. Egal, A. Cocherie, M. Tegyey and J. P. Milesi, "Contrasting Mechanism of Crustal Growth: Geodynamic Evolution of the Paleoproterozoic Granite-Greenstone Belts of French Guiana,” Precambrian Research, Vol. 92, No. 2, 1998, pp. 165-193. doi:10.1016/S0301-9268(98)00074-6 